\title{
Investigation of the relationship between exportin5 (XPO5) polymorphism and gastric cancer
}

\section{Exportin5 (XPO5) polimorfizmi ille mide kanseri arasındaki ilişkinin araştırılması}

\author{
Abdisa Tufa ${ }^{1}$, Ayça Taş²*, Tuğba Ağbektaş ${ }^{3}$, Ömer Topçu ${ }^{4}$, Solomon Genet ${ }^{1}$, Yavuz Silliğ ${ }^{3}$
}

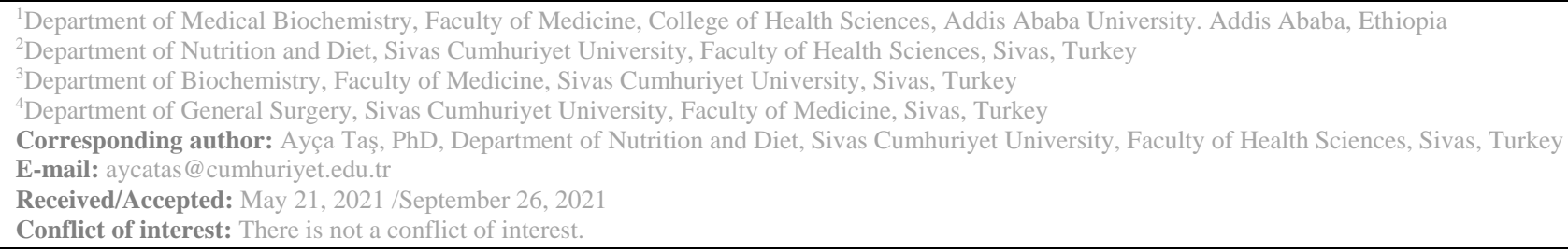

\section{SUMMARY}

Objective: We aimed to analyzed the association between gastric cancer and polymorphism of XPO5 gene.

Method: The polymorphism in the XPO5 gene (rs11544382) was determined in 120 individuals (60 gastric cancer patients; 60 healthy controls) using Real-Time PCR method.

Results: The comparison of gastric cancer patients and controls revealed a statistically significant relationship for alcoholic drink consumption $(p<0.05)$. The relationship between XPO5 gene (rs11544382) polymorphism and gastric cancer was statistically not significant. There was no a statistically significant relationship between mutant (GG) genotype with both wild type (AA) and heterozygous $(\mathrm{AG})$ polymorphic genotypes when evaluated in XPO5 polymorphism gastric cancer patients and control groups $\left(\chi^{2}: 0.12, p=0.729\right)$. The heterozygous $(\mathrm{AG})$ was dominant in gastric cancers patients and control subjects, 93.3 and $91.7 \%$ respectively.

Conclusions: This study provides information about allele and genotype frequency distribution of XPO5 gene polymorphism (rs11544382) in Turkish At the same time, AG genotype was found to be dominant in gastric cancer patients and their controls.

Keywords: XPO5 gene, gastric cancer, polymorphism, rs11544382.
(iD) Abdisa Tufa
(iD) Ayça Taş
(D) Tuğba Ağbektaş
(iD) Ömer Topçu
(iD) Solomon Genet
(D) Yavuz Siliğ

\section{ÖZET}

Amaç: XPO5 geninin polimorfizmi ile mide kanseri arasındaki ilişkiyi incelemeyi amaçladık.

Yöntem: XPO5 genindeki (rs11544382) polimorfizmi, Real-Time PCR yöntemi kullanılarak 120 kişide (60 mide kanseri hastası; 60 sağlıklı kontrol) belirlendi.

Bulgular: Mide kanseri hastaları ile kontrollerin karşılaştırıldığında alkollü içecek tüketimi açısından istatistiksel olarak anlamlı bir ilișki olduğunu ortaya koymuștur ( $<<0,05)$. XPO5 geni (rs11544382) polimorfizmi ile mide kanseri arasındaki ilișki istatistiksel olarak anlamlı değildi. XPO5 gen polimorfizmi mide kanseri hastalarında ve kontrol grupları arasında değerlendirildiğinde, mutant (GG) genotipi ile hem yabanıl tip (AA) hem de heterozigot (AG) polimorfik genotipler arasında istatistiksel olarak anlamlı bir ilişki yoktu $(\chi 2: 0.12, p=0.729)$. Heterozigot (AG) genotipi, sırasıyla \% 93.3 ve \% 91.7 oran ile mide kanserli hastalarda ve kontrol gruplarında baskın olduğu belirlendi.

Sonuç: Bu çalışma, Türk popülasyonunda XPO5 gen polimorfizminin (rs11544382) allele ve genotip frekans dağılımı hakkında bilgi vermektedir. Aynı zamanda AG genotipi'nin mide kanseri hastalarında ve kontrollerinde baskın olduğu bulunmuştur.

Anahtar sözcükler: XPO5 gen, mide kanseri, polimorfizm, rs11544382 


\section{INTRODUCTION}

Gastric cancer (GC) is the fifth most frequently diagnosed cancer and the third leading cause of cancer death in the world based on GLOBOCAN 2018 data. $^{1}$ GC remains a major health problem worldwide. It is also one of the leading causes of cancer-related deaths worldwide. ${ }^{2}$ The incidence of GC varies among different geographical regions and ethnicities. Accordingly, it has been determined that it is highest in Japan, China, Far East countries, Russia, the Middle East region and the lowest in Central Africa on the Pacific coast of the South American continent. ${ }^{3}$ In Turkey, which ranks fourth in the GC incidence of deaths due to cancer and is the fifth. Additionally, in Turkey, there is some variability in the incidence rate between regions, with the East exhibiting a greater cases compared to the West. ${ }^{4}$ Although there are many important developments in the diagnosis and treatment of GC, unfortunately, it is still detected after the late stage. The 5-year GC survival rate is less than $30 \%$ in developed countries and around $20 \%$ in developing countries. It has been found that due to this condition, the mortality rate of GC is higher than most other common malignancies, including colorectal, breast, and prostate cancers. ${ }^{5}$

Gastric cancer results from a collection of environmental factors and accumulation of specific genetic alterations. Despite declining trends worldwide, prevention of GC should stay priority. ${ }^{6}$ Family history, intestinal metaplasia, salt intake, smoking, alcohol and $\mathrm{H}$. pylori are among the most important risk factors for the development of GC. ${ }^{7}$ Genetic factors pose a risk for GC is still not fully understood. However, new studies continue to determine the important relationships between genetic variants and GC risk. ${ }^{8}$

Single nucleotide polymorphism (SNP) is the most common type of inherited variation that can be used to determine the specific disease risk. ${ }^{9}$ Recent studies show that microRNA-associated SNPs are associated with the development of a large number of human cancers, including GC, and can be used as predictive biomarkers. ${ }^{10}$ miRNAs are small noncoding RNAs of 1925 nucleotides in length and are known to regulate several neighbor protein-coding genes both in plants and animals. ${ }^{11}$ miRNAs are also important regulators of gene expression that bind complementary target mRNAs and repress their expression. ${ }^{12}$ It has unique, diverse expression patterns and affect many cellular processes and developmental pathways. $^{13}$ During miRNA biogenesis, XPO5 is a key factors for the transportation pathway of miRNA from the nucleolus and it can be a rate limiting step for
miRNA development, so its impairment could lead to pre-miRNA trapping in the nucleolus, influencing the risk of cancer. ${ }^{14}$ Abnormal expression of XPO5 protein has been found in many human cancers. ${ }^{15}$ Increasing evidence reveals the existences of SNPs in XPO5 gene. For example, patients with AA genotype of rs11077 showing an increased risk of GC. ${ }^{16}$ The causes and how to develop the multi targeted preventive strategies for GC will be a major challenge in future. In this study, it was aimed to determine the relationship between XPO5 gene (rs11544382) polymorphism and GC in the Turkish population.

\section{MATERIAL AND METHODS}

\section{Study design}

This study was conducted at Sivas Cumhuriyet University, which is one of the oldest, the largest and cancer referral hospital in Sivas Turkey where patients have been referred from different corners of the region. Cross sectional case control study was conducted and cases and controls were recruited from the same study area and at the same study period to reduces geographical and timing biases to the study population. Ethics committee document was taken from Sivas Cumhuriyet University Ethics Committee. 60 patients were collected from the date on which the ethical committee approval was obtained. (Sivas Cumhuriyet Ethics Committee, Approval Date: 17.04.2019; Numbered: 2019-04/43).

\section{Source, study population and patient recruitment}

The informed consent was obtained from all patients who were without previous cancer history, not under medication and capable to give written informed consent. All groups participated in the study filled out a short questionnaire containing questions about smoking, alcohol consumption and family history of cancer. Following the participant's informed consent signature and enrolment, trained nurses were administered a brief questionnaire inquiring about social-demographics and medications. During the visit of patients to the clinic, senior pathologist was histologically confirmed the diagnosis of GC for eligibility of the participants. They were informed about the study then referred to the study coordinator. The information gathered through the proposed questionnaire is not always in medical record and complements the details of clinical evaluation extracted by the research clinicians. In the current study, a total of 120 study participants (60 GC and 60 control) were investigated. Samples were taken from 60 patients diagnosed with GC at Cumhuriyet 
University, Faculty of Medicine (Sivas referral hospital). The control group consisted of individuals without any chronic disease and family history of cancer. No restriction was made in terms of age and gender in the control group. In addition, all patient and control groups included in the study consisted of individuals born in the same country.

\section{General information about patients and control groups}

Patients were recruited between February 2018 to February 2019 at Cumhuriyet University Faculty of Medicine, Department of General Surgery. The patients were diagnosed as having gastric cancer. Control group of the same age and gender proportion were recruited from various departments (Physical therapy, orthopedics, eye clinic) which composed of individuals who have not been diagnosed with any cancer. In this study all patients and controls were interviewed face to face and interviews were recorded on the predesigned questionnaire.

\section{Quality control and safety issue}

During sample collection and processing, all biohazard safety guidelines and regulations including Universal Precautions for Handling Human Specimens were followed. Clinical samples were handled under certified biological cabinet.

\section{DNA Isolation method}

Peripheral blood samples of $2 \mathrm{~mL}$ were taken from all subjects into blue-capped citrate tubes. Genomic DNA isolation from these samples was performed by high salt concentration DNA isolation method. ${ }^{17}$

\section{XPO5 Genotyping}

Allelic gene of XPO5 rs11544382 was analyzed by Real-Time PCR using hydrolysis probes and was studied under optimized conditions. The XPO5 rs11544382 (A/G) polymorphism was detected using the SNP sig Real Time Genotyping kit (Jena Bioscience) with double label fluorescent probes (FAM-VIC). RT-PCR condition is first denaturation $\left(95^{\circ} \mathrm{C}, 2\right.$ minutes), 15 cycles of denaturation $\left(95^{\circ} \mathrm{C}, 2\right.$ minutes), first extension $\left(60^{\circ} \mathrm{C}, 60 \mathrm{~s}\right)$ and 40 cycles of second denaturation $\left(95^{\circ} \mathrm{C}, 15 \mathrm{~s}\right)$ and second extension steps $\left(68^{\circ} \mathrm{C}, 60 \mathrm{~s}\right)$ as per kit protocol. Fluorogenic data were obtained from the orange (FAM) and yellow (VIC) channels at the end of the second extension cycle. Following SNP analysis, the amplification marked with FAM showed the A allele, the wild type allele. The amplification marked with VIC showed the G allele, that is, the mutated allele. The amplified PCR product was genotyped for the XPO5 rs11544382 (A/G) polymorphism by allelic separation according to the kit protocol (Figure 1). In addition, heterozygous (AG), mutant (GG) and wild type (AA) genotype distributions of the disease are shown in table 1.

Table 1: Demographic characteristics of the study groups $(n=120)$

\begin{tabular}{|l|c|c|}
\hline \multicolumn{1}{|c|}{ Variable } & $\begin{array}{c}\text { Controls } \\
\mathbf{n}(\boldsymbol{\%})\end{array}$ & $\begin{array}{c}\text { Gastric Cancer } \\
\text { n (\%) }\end{array}$ \\
\hline Sample size & 60 & 60 \\
\hline Sex & & $48(80.0)$ \\
\hline Males & $49(81.70)$ & $12(20.0)$ \\
\hline Females & $11(18.30)$ & $40-85$ \\
\hline Age(year) & $48-90$ & \\
\hline Range & & $60.00 \pm 9.71$ \\
\hline Means \pm SD & $59.61 \pm 10.06$ & $59.58 \pm 12.98$ \\
\hline Males & $60.45 \pm 9.40$ & $27(62.50)$ \\
\hline Females & & $26(54.20)$ \\
\hline Smoking History & $34(76.40)$ & $1(8.30)$ \\
\hline Smoker & $33(67.30)$ & $17(48.00)$ \\
\hline Males & $1(9.10)$ & $15(3.30)$ \\
\hline Females & & $2(16.70)$ \\
\hline Alcoholic Drink Consumption & $4(8.20)$ & $6(10.00)$ \\
\hline Yes & $4(8.20)$ & $0(0.00)$ \\
\hline Males & $10(16.70)$ & \\
\hline Females & & \\
\hline Family history of cancer & & \\
\hline
\end{tabular}




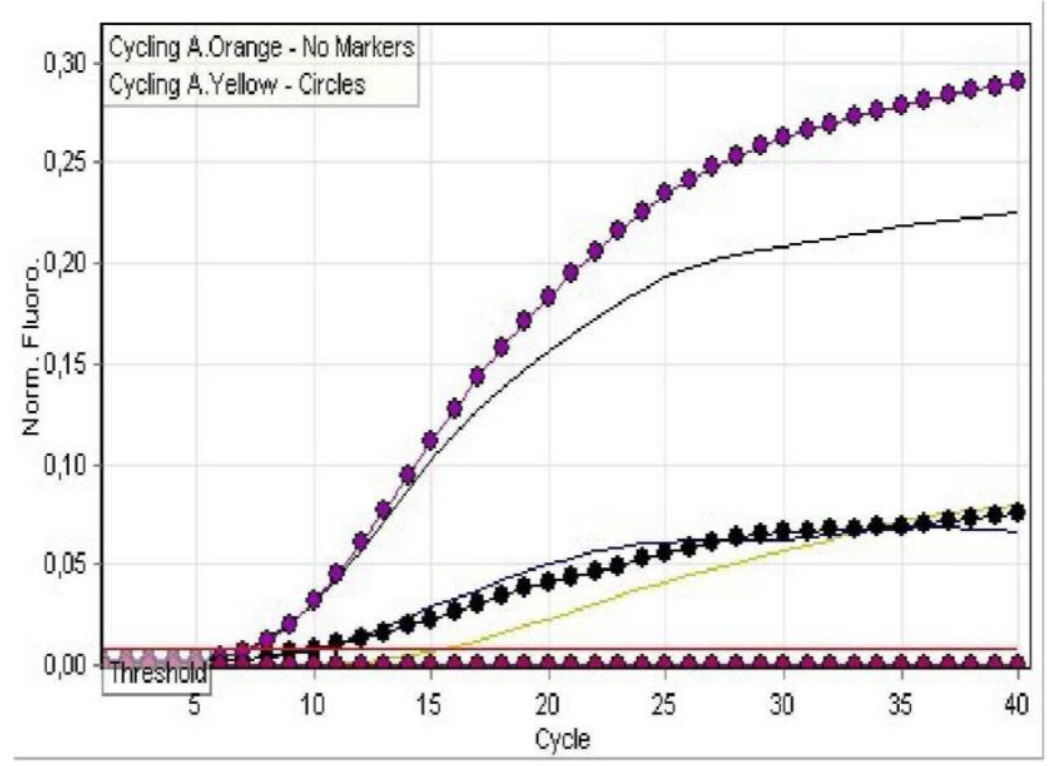

Graph 1:

Fig. 1: The genetic variant of XPO5 polymorphism (rs11544382) was detected by real-time PCR and allele discrimination

\section{Statistical analysis}

In this study, GC and XPO5 gene rs11544382 polymorphism was investigated. The relationship between smoking habits, alcohol habits and family history of cancer were analyzed using statistical software package(SPSS) Version 25.0 (SPSS, Inc., Chicago, IL, USA). GC and genotype-associated odds ratios (ORs) were determined by logistic regression analysis at $95 \%$ confidence interval (CIs). Demographic characteristics of the patient and control groups were evaluated using Student's t-test. Fischer's exact test (two-sided) was used to compare the gender distribution. The relationship between genotype and allele was determined by Hardy-Weinberg balance. Pearson's $\chi 2$ test was used to determine whether there was a significant difference in allele and genotype frequencies between patients and control groups. Logistic regression analysis was performed to evaluate the interaction between age, sex, and all genotypes. $p$ value $>0.05$ was considered statistically significant.

\section{RESULTS}

In this study $60 \mathrm{GC}$ patients and 60 control subjects were included. The data gathered through questionnaire (demographic data) and laboratory results obtained from samples collected from patients (lab results) were recorded and statistically analyzed. The data is tabulated and shown in table 2. The distribution of sex, age and ethnic origin of the study population was similar. There was no significant difference in gender between the groups (male: 48 (80.00\% vs 49 (81.70\%); female: 12 $(20.00 \%)$ and $11(18.30 \%)$. Similarly, the mean age of the patient and control groups was $59.6 \pm 10.00$ (male; 60.00 \pm 9.71 , female; 59.58 \pm 12.98 ) and $60.00 \pm 9.71 \quad$ (male; 59.6 \pm 10.06 , female; $60.45 \pm 9.40$ ) (Table 2). Of the total number of gastric patients, 27 (62.50\%) were smokers and 34 (76.40\%) individuals in the control group were found to be smoking. Among of the control group smokers, $33(67.30 \%)$ were males and $1(9.10 \%)$ was a female. Of the total, $26(54.20 \%)$ gastric cancer patients were males and $1(8.30 \%)$ was a female. When the GC patients and controls were evaluated for alcohol consumption, 4 (8.20\%) individuals in the control group were found alcohol users. All individuals who drink alcohol in the control groups $4(8.20 \%)$ were males and none of the females drink alcohol. 
Table 2: Genotype distributions of rs 11544382 polymorphism.

\begin{tabular}{|l|l|l|l|l|l|}
\hline No. & Colour & Name & Genotype & $\begin{array}{l}\text { Cycling } \\
\text { A.Orange }\end{array}$ & Cycling A.Yellow \\
\hline 1 & & Case1 & Wild Type(AA) & Reaction & No Reaction \\
\hline 2 & & Case2 & Heterozygous(AG) & Reaction & Reaction \\
\hline 3 & & wild & Wild Type(AA) & Reaction & No Reaction \\
\hline 4 & & Mutant & Mutant(GG) & No Reaction & Reaction \\
\hline 5 & & Negative & & No Reaction & No Reaction \\
\hline
\end{tabular}

Family history of cancer was also examined and 10 of the controls $(48.80 \%)$ were found to be firstdegree relatives of cancer while in the patient group, $6(25.00 \%)$ patients were found to be in first degree relatives of cancer patients (Table 2). Regarding tobacco use, $45.00 \%$ of the patients and $56.70 \%$ of the controls were smokers. The percentage of patients and controls in terms of smoking is similar to each other. There was no statistically significant relationship between the patient and control groups in terms of smoking history. It is understood that it does not pose a risk (OR: 95\% CI:0.62 (0.30-1.38) (Table 3). Analysis of gastric cancer patients and control group, based on alcohol use, the frequency of alcohol use in patients is $28.30 \%$ but $6.70 \%$ in controls respectively. The percentage of alcohol use among the patients was higher than the control group.

Table 3: Interaction between gastric cancer and smoking, drinking habit and family history of cancer.

\begin{tabular}{|c|c|c|}
\hline & $\begin{array}{c}\text { Control } \\
\text { n }(\%) \\
\end{array}$ & $\begin{array}{c}\text { Gastric Cancer } \\
\text { n }(\%) \\
\end{array}$ \\
\hline \multicolumn{3}{|l|}{ Smoking Habit } \\
\hline Smokers & $34(56.70)$ & $27(45.00)$ \\
\hline Non-smokers & $26(43.30)$ & $33(55.00)$ \\
\hline$\chi 2$ & \multicolumn{2}{|c|}{1.634} \\
\hline$p$ & \multicolumn{2}{|c|}{0.201} \\
\hline Crude OR $(95 \% \mathrm{CI})$ & \multicolumn{2}{|c|}{$0.62(0.30-1.28)$} \\
\hline Adjusted*OR $(95 \% \mathrm{CI})$ & \multicolumn{2}{|c|}{$0.42(0.18-1.01)$} \\
\hline \multicolumn{3}{|l|}{$\begin{array}{l}\text { Alcoholic Drink } \\
\text { Consumption }\end{array}$} \\
\hline Yes $(\%)$ & $4(6.70)$ & $17(28.30)$ \\
\hline No $(\%)$ & $56(93.30)$ & $43(71.70)$ \\
\hline$\chi^{2}$ & \multicolumn{2}{|c|}{11.79} \\
\hline$p$ & \multicolumn{2}{|c|}{0.002} \\
\hline Crude OR $(95 \%$ CI $)$ & \multicolumn{2}{|c|}{$5.53(1.73-17.64)$} \\
\hline Adjusted*OR:(95\%CI) & \multicolumn{2}{|c|}{$6.79(2.00-22.95)$} \\
\hline \multicolumn{3}{|l|}{ Family History of Cancer } \\
\hline Yes $(\%)$ & $10(16.70)$ & $6(10.00)$ \\
\hline No $(\%)$ & $50(83.30)$ & $54(90.00)$ \\
\hline$\times 2$ & \multicolumn{2}{|c|}{1.15} \\
\hline$p$ & \multicolumn{2}{|c|}{0.283} \\
\hline Crude OR (95\% CI) & \multicolumn{2}{|c|}{$0.55(0.18-1.64)$} \\
\hline Adjusted*OR:(95\% CI) & \multicolumn{2}{|c|}{$0.64(0.20-2.06)$} \\
\hline
\end{tabular}


Statistically significant differences were found between the patient and control groups in terms of alcohol consumption. It has been found $(\chi 2: 11.79$, $p=0.002)$. Use of alcohol for gastric cancer $\chi 2$ method (OR: 5.53 of 95\% CI:1.73-17.64). The medical history of family members was also examined for association with GC (Table 3). Comparison of familial history of cancer among GC patients and controls showed that the prevalence was $10.00 \%$ and $16.70 \%$ respectively. But the difference was not statistically significant $(\chi 2: 1.15, p=0.283)$ (Crude OR:95 \%CI: 0.55(0.181.64) (Table 3).

In this study, the relationship between the XPO5 gene polymorphism rs11544382 (A/G) and GC was tried to be determined in the Turkish population. The s11544382 polymorphism in the XPO5 gene was determined by RT-Polymerase chain reaction method in GC patients and healthy controls. The A and $\mathrm{G}$ allele XPO5 gene rs11544382 polymorphism of GC patients and controls were analyzed. The result obtained showed that there was no statistically significant difference between the groups $(\chi 2: 0.02, p=0.896)$ (OR: 1.03 of $95 \%$ CI: 0.60-1.17) (Table 4). When AA genotype distributions were analyzed, it was found that there were $4(6.70 \%)$ gastric cancer patients and $5(8.30 \%)$ control group had it but a statistically significant correlation was not obtained between them $(\chi 2: 0.12, p=0.729)$ (Table 4).

Table 4: Genotypic and allelic frequencies of XPO5 (rs11544382) in gastric cancer and control subjects.

\begin{tabular}{|c|c|c|c|c|c|c|}
\hline $\operatorname{rs11544382}(\mathrm{A} / \mathrm{G})$ & $\begin{array}{c}\text { Control } \\
\text { n }(\%)\end{array}$ & $\begin{array}{c}\text { Gastric Cancer } \\
\text { n }(\%)\end{array}$ & $X^{2}$ & $\begin{array}{c}p \\
\text { value }\end{array}$ & $\begin{array}{c}\text { Crude OR } \\
(95 \% \text { CI })\end{array}$ & $\begin{array}{l}\text { Adjust OR } \\
(95 \% \text { CI })\end{array}$ \\
\hline \multicolumn{7}{|l|}{ Allele Frequence } \\
\hline$A$ & $65(54.10)$ & $64(53.30)$ & \multirow{2}{*}{0.02} & \multirow{2}{*}{0.896} & \multirow{2}{*}{$1.03(0.60-1.17)$} & \multirow{2}{*}{-} \\
\hline$G$ & $55(45.90)$ & $56(46.70)$ & & & & \\
\hline \multicolumn{7}{|l|}{ Genotype Frequence } \\
\hline$A A$ & $5(8.30)$ & $4(6.70)$ & \multirow{2}{*}{0.12} & \multirow{2}{*}{$0.729^{\mathrm{a}}$} & \multirow{2}{*}{$1.27(0.32-4.99)$} & \multirow{2}{*}{$1.13(0.33-5.07)$} \\
\hline$A G$ & $55(91.7 \%)$ & $56(93.30)$ & & & & \\
\hline$G G$ & $0(0.00)$ & $0(0.00)$ & - & - & - & - \\
\hline
\end{tabular}

${ }^{a}$ Fisher's exact test.

\section{DISCUSSION}

Genetic background plays an important role in the development of GC, which is a genetic disease caused by the interaction of genes and environment. ${ }^{18}$ In addition, individual genetic factors play an important role in the susceptibility and progression of GC. ${ }^{19} \mathrm{GC}$ is a multifactorial and complicated disease in which gene effects have been considered as a predominant component. Differences in ethnic origin, demographic structure, socioeconomic development, and lifestyle experiences all together offer opportunities to study the effect of genetic polymorphisms on susceptibility to GC. ${ }^{20}$ The current understanding of genetic polymorphism and GC development is largely based on studies conducted in Asian and Caucasian populations. ${ }^{21}$

Many studies have revealed that GC risk is associated with polymorphisms in genes involved in DNA synthesis and repair, inflammatory response, metabolic enzymes, and oxidative damage. ${ }^{22}$ Human miRNA biogenesis is processed inside the nuclues and cytoplasm as a step wise. First, the miRNA gene is processed to produce a pri miRNA. Pri-miRNA is excised by the microprocessor containing DROSHA and its cofactor DGCR8 and produces 60-70 nucleotide pre-mRNA. ${ }^{23}$ These precursor molecules are then transferred to the cytoplasm and XPO5 and RANGTPase act on these precursors. In addition, the RNase III enzyme is cleaved by DICER into $~ 22$ nt miRNA duplexes.

$X P O 5$ rate limiting step in miRNA biogenesis and its alterations, either variations in expression levels or as a consequence of single nucleotide polymorphism, have been shown to influence cancer development or prognosis in several tumor types. ${ }^{14}$ SNPs are variations in a single nucleotide that ocur at a specific position in the genome and are present in at least $1 \%$ of the population. When they occur in critical regions of genes they can lead to alterations in gene expression, transcription factor binding, histone modifications, methylation among others, which influence cell metabolism and can be correlated with cancer risk. ${ }^{24}$ 
MicroRNA-SNPs have generated increasing interest in biological and medical sciences. ${ }^{25}$ There is an evidence that alterations in the miRNA biogenesis and processing machinery can influence the pattern of expression of miRNAs with consequences for cellular functioning, subsequently impact tumorigenesis. ${ }^{26,27}$

Many previous results showed that there are five NPs in XPO5 related to cancer outcomes, namely rs11077, rs11544382, rs34324334, rs2227301 and rs699937. Regarding the four XPO5 SNPs related to cancer outcome, rs 11544382 , rs34324334, rs2227301 and rs699937, the information is limited. The rs34324334 and rs11544382 are two missense SNPs, resulting in S241N and M115T alterations, respectively. ${ }^{28}$ Different studies have revealed that XPO5 rs11077 is associated with various types of cancer. As an example, it has been determined that the rs11077 polymorphism is independently associated with worse survival in patients with hepatocellular carcinoma with the AA genotype. ${ }^{29}$ In addition, XPO5 overexpression has been found to be associated with poor survival in colorectal cancer patients. ${ }^{30}$ It has been reported that the overexpression of XPO5 causes cell proliferation and metastasis and thus supports the aggression of melanoma cancer cells. ${ }^{31}$ Those studies suggest a potential role for the microRNA biogenesis gene, XPO5, in human cancers.

In this study, the allelic and genotypic frequency distribution of rs11544382 polymorphisms in the XPO5 gene was compared with the studies conducted with other ethnic groups. The frequencies of $\mathrm{G}$ and $\mathrm{A}$ alleles in the study population were $45.90 \%$ and $54.10 \%$, respectively, and the frequencies of GG, AG and AA genotypes were $0.0 \%, 91.70 \%$ and $8.30 \%$, respectively. The distribution of all three genotypes was within Hardy-Weinberg $\left(X^{2}=0.12, p=0.729\right)$ (Table 4).

In this study, the raw OR value of cancer in terms of alcohol drinking status of the GC patient was 5.53 (1.73-17.64) in the GC patient and control group. It shows a relationship between GC and alcohol consumption ( $p=0.002$; Table 3$)$. This result agreement with the previous report done by scholars. ${ }^{21}$ Beside to this, GC patients and control subjects were evaluated by logistic regression analysis for smoking habits. No statistically significant difference was identified between GC patients and smoking habits in the Turkish population investigated in the current study $(p=0.201$, Table 3$)$. This result in line with previous reported that on smoking history of case-control, there were no statistically significant associations between them $(\mathrm{OR}=0.99 ; 95 \% \quad \mathrm{CI}, 0.50-1.97$; $p=0.989){ }^{32}$

Literature in research, in different parts of the world, including in Turkish GC examining the rs11544382 polymorphism in patients with XPO5 has not been observed in any study. Therefore, the study is important in that it is the first to evaluate the relationship between the polymorphic variants of the XPO5 rs11544382 polymorphism and GC. In the present study, the combined variant genotypes of rs11544382 not associated with GC risk ( $\mathrm{OR}=1.27,95 \% \mathrm{CI}: 0.32-4.99)$, as compared to the homozygous common genotype (Table 4). Even though statistically not significant, demonstrates that mutations rs11544382 (M1115T) in an important miRNA biogenesis gene, XPO5, might have associations with GC risk clinically. In the XPO5 gene, rs11544382 (A> G) SNP was found to be significantly associated with breast cancer risk (OR=1.59; CI:1.06-2.39) compared to homozygous controls in Caucasian populations. ${ }^{33}$ This result inline with findings from the previous study which showed the significant association between XPO5 rs1 1544382 and risk of breast cancer. $^{28}$

Based up on the present study the following conclusions are arrived at: AG genotype is predominant in gastric cancer patients and controls and that the AA genotype has a protective effect against GC. The polymorphic genotypes of XPO5 rs11544382 statistically not associated with GC risk as compared to the homozygous common genotype. However, it might have associations with GC risk clinically. And also this study adds evidence on the association between established risk factors of gastric cancer such as smoking, drinking alcohol and family history of cancer. Alcohol drinking status and GC incidence association were statistically significant.

\section{CONCLUSION}

In conclusion, the present study reports the distribution of of XPO5 gene (rs11544382) phenotypes and genotypes in a group of individuals in Turkish population. It was found that the AG genotype is predominant in gastric cancer patients and controls and that the AA genotype has a protective effect against GC. Given the evidence showing that changes in microRNA expression play an important role in the initiation and progression of cancer, polymorphism in the XPO5 gene responsible for microRNA biogenesis may play a central role in gastric cancer parthenogenesis. 


\section{Acknowledgments}

We would like to thank Dr. Ziynet ÇINAR for her support for the statistical analysis.

\section{Conflict of Interest}

The authors declare no competing interests.

\section{REFERENCES}

1. Bray F, Ferlay J, Soerjomataram I, Siegel RL, Torre LA, et al. Global cancer statistics 2018: GLOBOCAN estimates of incidence and mortality worldwide for 36 cancers in 185 countries. CA: A Cancer Journal For Clinicians 2018; 68: 394-424.

2. Ajani JA, Lee J, Sano T, Janjigian YY, Fan D. et al. Gastric adenocarcinoma. Nature Reviews Disease Primers 2017; 3.1: 1-19.

3. Majidi A, Majidi S, Salimzadeh S, KhazaeePool M, Sadjadi A. et al. Cancer screening awareness and practice in a middle income country; A Systematic Review from Iran. APJCP 2017; 18: 3187.

4. Guner A. Recent trends of gastric cancer treatment in Turkey. Transl Gastroenterol Hepatol 2017; 2.

5. Sitarz R, Skierucha M, Mielko J, Offerhaus GJA, Maciejewski R. et al. Gastric cancer: epidemiology, prevention, classification, and treatment. Cancer Manag Res 2018; 10: 239.

6. Buckland G, Travier N, Huerta J, Bueno-deMesquita H, Siersema P. et al. Healthy lifestyle index and risk of gastric adenocarcinoma in the EPIC cohort study. Int J Cancer 2015; 137: 598606.

7. Take S, Mizuno M, Ishiki K, Yoshida T, Ohara N.et al. The long-term risk of gastric cancer after the successful eradication of Helicobacter pylori. J. Gastroenterol 2011; 46: 318-324.

8. Qiu L-X, Cheng L, He J, Zhou Z-R, Wang MY. et al. PSCA polymorphisms and gastric cancer susceptibility in an Eastern Chinese population. Oncotarget 2016; 7: 9420.

9. Goldstein DB, Ahmadi KR, Weale ME, Wood NW. Genome scans and candidate gene approaches in the study of common diseases and variable drug responses. Trends Genet 2003; 19: 615-622.

10. Xie W-Q, Tan S-Y, Wang X-F. MiR-146a rs2910164 polymorphism increases risk of gastric cancer: a meta-analysis. World J Gastroentero 2014; 20: 15440.
11. Treiber T, Treiber N, Meister G. Regulation of microR NA biogenesis and its crosstalk with other cellular pathways. Nat Rev Mol Cell Biol 2019; 20: 5-20.

12. Michlewski G, Cáceres JF. Post-transcriptional control of miRNA biogenesis. Rna. 2019; 25: 116.

13. Quinn JJ, Chang HY. Unique features of long non-coding RNA biogenesis and function. Nat Rev Genet 2016;17: 47.

14. Patrão AS, Dias F, Teixeira AL, Maurício J, Medeiros R. XPO5 genetic polymorphisms in cancer risk and prognosis. Pharmacogenomics. 2018; 19: 799-808.

15. Esteller M. Non-coding RNAs in human disease. Nat Rev Genet 2011 12: 861.

16. Xie Y, Wang Y, Zhao Y, Guo Z. Singlenucleotide polymorphisms of microRNA processing machinery genes are associated with risk for gastric cancer. Onco Targets Ther 2015; 8: 567.

17. Miller S, Dykes D, Polesky H. A simple salting out procedure for extracting DNA from human nucleated cells. Nucleic Acids Res 1988; 16: 1215.

18. Zhao L, Zhang Z, Lin J, Cao L, He B. et al. Complement receptor 1 genetic variants contribute to the susceptibility to gastric cancer in Chinese population. J. Cancer 2015; 6: 525.

19. Song X, Zhong H, Wu Q, Wang M, Zhou J. et al. Association between SNPs in microRNA machinery genes and gastric cancer susceptibility, invasion, and metastasis in Chinese Han population. Oncotarget 2017; 8: 86435.

20. Chiurillo MA. Role of gene polymorphisms in gastric cancer and its precursor lesions: current knowledge and perspectives in Latin American countries. World J Gastroentero 2014; 20: 4503.

21. Atabey M, Taş A, Ağbektaş T, Bostanci ME, Topcu Ö. Et al. Investigation of the relationship between $\beta 2$-adrenergic receptor ( $\beta 2$-AR) polymorphism and gastric cancer. Cumhuriyet Medical Journal 2018; 40: 284-290.

22. Peng S, Kuang Z, Sheng C, Zhang Y, Xu H. et al. Association of microRNA-196a-2 gene polymorphism with gastric cancer risk in a Chinese population. Digest Dis Sci 2010; 55: 2288-2293.

23. Finnegan EF, Pasquinelli AE. MicroRNA biogenesis: regulating the regulators. Crit Rev Biochem Mol 2013; 48: 51-68. 
24. Hubner RA, Houlston RS. Single nucleotide polymorphisms and cancer susceptibility. The molecular basis of human cancer: Springer; 2017. p. 231-239.

25. Mishra PJ, Mishra PJ, Banerjee D, Bertino JR. MirSNPs or MiR-polymorphisms, new players in microRNA mediated regulation of the cell: Introducing microRNA pharmacogenomics. Cell Cycle. 2008; 7: 853-858.

26. Ryan BM, Robles AI, Harris CC. Genetic variation in microRNA networks: the implications for cancer research. Nat. Rev. Cancer 2010; 10: 389.

27. Huang J-T, Wang J, Srivastava V, Sen S, Liu SM. MicroRNA machinery genes as novel biomarkers for cancer. Front oncol 2014; 4: 113.

28. Leaderer D, Hoffman AE, Zheng T, Fu A, Weidhaas J. et al. Genetic and epigenetic association studies suggest a role of microRNA biogenesis gene exportin-5 (XPO5) in breast tumorigenesis. Int. J. Mol. Epidemiology Gene 2011; 2: 9 .
29. Liu S, An J, Lin J, Liu Y, Bao L. et al. Single nucleotide polymorphisms of microRNA processing machinery genes and outcome of hepatocellular carcinoma. PloS one 2014; 9: 92791.

30. Shigeyasu K, Okugawa Y, Toden S, Boland CR, Goel A. Exportin-5 functions as an oncogene and a potential therapeutic target in colorectal cancer. Clin Cancer Res 2017; 23: 1312-1322.

31. Ott CA, Linck L, Kremmer E, Meister G, Bosserhoff AK. Induction of exportin-5 expression during melanoma development supports the cellular behavior of human malignant melanoma cells. Oncotarget 2016; $7: 62292$.

32. Tas A, Atabey M, Caglayan G, Bostanci ME, Sehin BS. et al. Investigation of the association between the MDM2 T309G polymorphism and gastric cancer. Biomed Rep 2017; 7: 469-773.

33. Malhotra P, Read GH, Weidhaas JB. Breast Cancer and miR-SNPs: The Importance of miR Germ-Line Genetics. Non-coding RNA. 2019; 5: 27. 